\title{
NEW ACANTHODRILID SPECIES FROM MADAGASCAR (CLITELLATA, ACANTHODRILIDAE)
}

\author{
Yong Hong ${ }^{1}$, Malalatiana Razafindrakoto ${ }^{2}$, Eric Blanchart ${ }^{3}$ \\ Tímea Szederjesi ${ }^{4}$ and Csaba Csuzdi ${ }^{5}$
}
${ }^{1}$ Department of Agricultural Biology, College of Agriculture \& Life Sciences, Chonbuk National University, Jeonju, Republic of Korea; E-mail: geoworm@hanmail.net; https://orcid.org/0000-0002-1932-4983
${ }^{2}$ Laboratory of Radio-Isotopes, University of Antananarivo, Madagascar
E-mail: malalasraz@yahoo.fr; https://orcid.org/0000-0002-4596-4319
${ }^{3} I R D$, UMR EcoESSols, Laboratoire des RadioIsotopes, Université of Antananarivo, BP 3383, 101, Antananarivo, Madagascar; E-mail: eric.blanchart@ird.fr; https://orcid.org/0000-0002-5258-5069 ${ }^{4}$ Department of Zoology, Hungarian Natural History Museum, Budapest, Hungary
E-mail: t.szederjesi@gmail.com; https://orcid.org/0000-0001-7695-1468
${ }^{5}$ Department of Zoology, Eszterházy Károly University, Eger, Hungary
E-mail: csuzdi.csaba@uni-esztehazy.hu; https://orcid.org/0000-0002-0319-7836

During collecting trips to Madagascar in the last decade several Acanthodrilidae sensu lato species were collected. The newly acquired material expresses high variability of the excretory system containing meroic, holoic vesiculate and holoic avesiculate species. The possible relationships of the Malagasy acanthodrilids is discussed and five species; Acanthodrilus hesperus, Eodriloides metandricus, Howascolex proprioporus, Howascolex vohimanus and Vazimbascolex alaotranus spp. n. are described. Vazimbascolex gen. n. represents also a new genus to science. The holoic avesiculate Acanthodrilus majungianus Michaelsen, 1897 and $A$. voeltzkowi Michaelsen, 1897 are conditionally transferred to the South African genus Eodriloides Zicsi, 1998; Eodrilus dauphinianus Michaelsen, 1910 and Microscolex (Notiodrilus) hyalochaeta Michaelsen, 1907 to Howascolex Michaelsen, 1901.

Keywords: Malagasy region, earthworms, Oligochaeta, Opisthopora, Crassiclitellata, excretory system.

\section{INTRODUCTION}

Madagascar with its $c a 600,000 \mathrm{~km}^{2}$ territory represents the world's fourth largest island and one of the 25 biodiversity hotspot of the Earth (Myres et al. 2000). Interestingly, the earthworm fauna of Madagascar is poorly studied and there were only a couple of papers dealing with this important group of the soil fauna (Michaelsen 1897, 1907, Cognetti 1906) until a new research program (Faune-M) by the French Foundation for the Research on Biodiversity was launched in 2008. In the framework of this project several collecting trips have been organized to visit different parts of the island, resulted in describing nine new species in the endemic family Kynotidae raising the number of valid species in the family to 22 (Csuzdi et al. 2012, 2017a, RAzAfindRAKOTO et al. 2011, 2017). 
Apart from the kynotids one ocnerodrilid (Gordiodrilus madagascariensis Michaelsen, 1901) and five acanthodrilid species (Acanthodrilus majungianus Michaelsen, 1897; Acanthodrilus voeltzkowi Michaelsen, 1897; Howascolex madagascariensis Michaelsen, 1901; Microscolex (Notiodrilus) hyalochaeta Michaelsen, 1907 and Eodrilus dauphinianus Michaelsen, 1910) have previously been described, and in a recent paper (Csuzdi et al. 2016) another new species was added to this group; Howascolex farafangana Csuzdi, Razafindrakoto et Hong, 2016.

The taxonomy of the Malagasy endemic genus Howascolex is more or less settled (Julka 1988, Csuzdi et al. 2016) however, the proper genus in which the other four species (majungianus, voeltzkowi, dauphinianus and hyalochaeta) belong to is still uncertain. These species show basic acanthodrilin characters such as spermathecae in 8,9 , prostates in 17,19 , one strongly muscular gizzard in 5 and holoic? exoic avesiculate nephridial system. These characters exclude them from the genus Acanthodrilus which is characterised by vesiculate nephridia and known only from New Caledonia and the neighbouring islands (Jamieson \& Bennett 1979, Csuzdi et al. 2017b). Pickford (1937) examining the nephridial system of majungianus and voeltzkowi relegated these species to the Australian genus Eodrilus Michaelsen, 1907 which later proved to be a synonym of the Australian Diplotrema Spencer, 1900 (JAMieson 1971, Jamieson \& Dyne 1976, Dyne \& Jamieson 2004) therefore Fragoso \& Rojas $(2016,2018)$ list all the four species in this cul-de-sac genus containing different species from Central and South America as well.

On the basis of the bidiverticulate spermathecal condition of the South African Diplotrema-like species ZIcsi (1998) separated them to the newly erected genus Eodriloides. These South African species differ from the Australian Diplotrema also in the absence of the genital setae localised around the spermathecal pores. Two of the Malagasy acanthodrilid species (majungianus and voeltzkowi) fit completely to the diagnosis of Eodriloides therefore until a thorough revision of the whole Diplotrema group is done we relegate these two species to the African Eodriloides.

Microscolex (Notiodrilus) hyalochaeta was described on a single macerated specimen. It hasn't got spermathecal diverticulum at all and Michaelsen stated that there is a "ringförmige überwallung" (a circular thickening) around the oesophagus in segment 14. Michaelsen (1907) supposed that the specimen is holoic but he was not sure about it due to the bad conservation of the specimen. In the Vohimana Reserve we have found a similar species with adiverticulate spermathecae, calciferous glands (circular thickening around the oesophagus) in segment 15 and with large megameronephridia accompanied by several minute meronephridia. These specimens clearly differ in some details from hyalochaeta but surely belong to the genus Howascolex, therefore here we suggest relegating Microscolex (Notiodrilus) hyalochaeta Michaelsen, 1907 to the genus Howascolex. 
Eodrilus dauphinianus Michaelsen, 1910 was described on a single adult specimen from Fort Dauphin (now Taolagnaro, S. Madagascar). Its nephridial system is stated as "meganephridisch" but the specimen possesses well developed calciferous diverticula in segment 16 which is a typical Howascolex character. Also the structure of spermathecae is quite peculiar; the unstalked diverticulum surrounds almost completely the duct of the spermatheca and possesses two lateral bulging. This structure is completely identical with that of Howascolex madagascariensis described from Andrahomana just some $50 \mathrm{~km}$ west of Taolagnaro. As the real structure of the nephridial system is often overlooked (CsuzDi et al. 2016) and the presence of large calciferous glands posterior to the genital segments is a well defined character of Howascolex here we propose transferring Eo. dauphinianus to Howascolex as well.

Elaborating the acanthodriline material collected in different parts of Madagascar between 2008-2017 altogether six species were found of which five represent new species to science including one belonging to a new genus herewith described.

\section{MATERIAL AND METHODS}

Earthworms were collected primarily by using the diluted formaldehyde method (RAw 1959) supplemented with digging and hand-sorting. The material collected was killed in $75 \%$ ethanol and fixed in $4 \%$ formaldehyde solution. From each morpho-species a parallel material was conserved in $96 \%$ ethanol for DNA studies.

The material collected has been deposited in the Hungarian Natural History Museum (HNHM), the Zoological Museum of the University of Antananarivo (ZMUA) and in the National Institute of Biological Resources (NIBR).

\section{TAXONOMY}

Acanthodrilidae Claus, 1990

Eodriloides majungianus (Michaelsen, 1897) comb. n.

Acanthodrilus majungianus Michaelsen, 1897: 218.

Notiodrilus majungianus: Michaelsen 1900: 136.

Eodrilus majungianus: Michaelsen 1907: 141, Pickford 1937: 587.

Material examined. - HNHMAF/5688 1 ex. Ambodimanga, Ankarafantsika District, Madagascar, $16^{\circ} 19^{\prime} 27.91^{\prime \prime} S, 46^{\circ} 49^{\prime} 52.90^{\prime \prime} \mathrm{E}, 83 \mathrm{~m}$ a.s.l., mixed forest, soil and litter. Leg. 04.03.2017, Yong Hong \& Malalatiana Razafindrakoto (MD19).

Diagnosis - Clitellum on 13-18, prostate pores 17, 19 connected with almost straight genital grooves just outside setal line $b$. Spermathecae elongated oval with two diverticles on the opposite sides of the duct (Fig. 1). The penial 

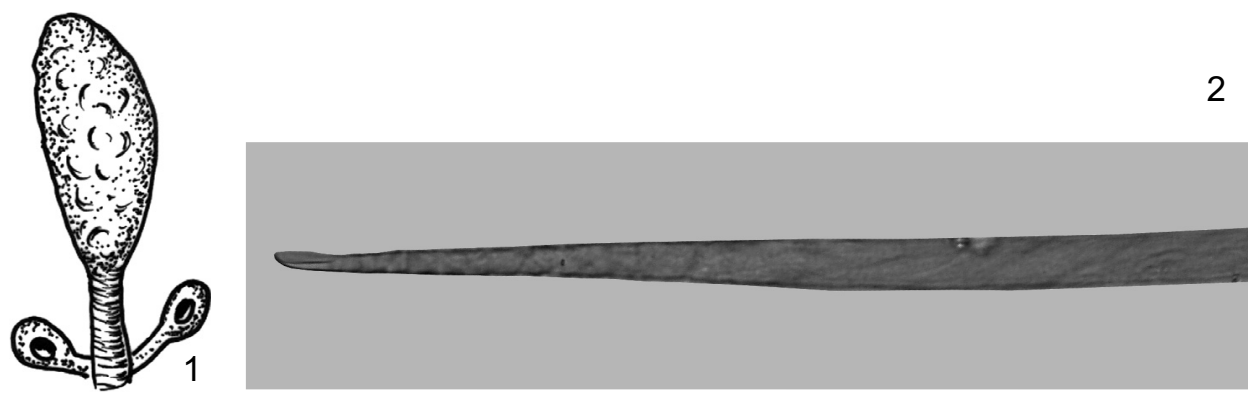

Figs 1-2. Eodriloides majungianus (Michaelsen, 1897): 1 = spermatheca, 2 = penial seta

setae slightly spatulate, $0.57 \mathrm{~mm}$ long and $0.013 \mathrm{~mm}$ wide, ornamented with scattered small serrations (Fig. 2)

Remarks - Our specimen fits well to the original description of $\mathrm{MI}-$ CHAELSEN (1897). The only notable difference is in the length of the clitellum which is stated on 13-17 by Michaelsen, but remarked that the hind end of the clitellum is not fully developed yet.

\section{Eodriloides metandricus Csuzdi, Razafindrakoto et Hong sp. n.}

(Figs 3-6)

Material examined - Holotype: HNHM AF/5689 clitellate adult, Tsararano, Marovay District, Madagascar, $16^{\circ} 10^{\prime} 55.99^{\prime \prime} \mathrm{S}, 46^{\circ} 39^{\prime} 44.95^{\prime \prime} \mathrm{E}, 48 \mathrm{~m}$ a.s.l. mixed forest, soil and litter. 03.03.2017, Leg. Yong Hong \& Malalatiana Razafindrakoto. Paratypes: HNHM AF/5690 3 clitellate adult +13 aclitellate adult ex., HNHM AF/5691 2 clitellate adult +9 aclitellate adult ex. Locality and date same as of Holotype. paratus.

Etymology - The specific epithet refers to the metandric condition of the male ap-

Diagnosis - Length 86-96 mm, diameter 3-3.5 mm. Colour pale, pigmentation lacking. First dorsal pore in 7/8. Clitellum saddle-shaped on 13-19. 우 14 paired, presetal outside $b$. Prostatic pores 17, 19. Spermathecal pores large in $7 / 8,8 / 9$, spermathecae with elongated oval ampoule, and an equally long duct bearing a pair of acinous diverticula at the basis of the duct. Gizzard large in 5 , last pair of hearts in 13. Calciferous glands lacking, vascular oesophagus in 9-12. Excretory system holoic avesiculate. Functionally metandric, vesicles in 12. Penial setae present, length $1 \mathrm{~mm}$, diameter $0.035 \mathrm{~mm}$. Tip slightly bent, ornamentation dense transversal serrations.

Description - Length of the holotype $95 \mathrm{~mm}$, width (postclitellar) $3.5 \mathrm{~mm}$. Segments No. 180, the last 15 segments regenerated. Paratypes $86-96 \mathrm{~mm}$ in length and $3 \mathrm{~mm}$ in diameter, segment No. 188-192. Colour greyish, pigmentation absent. Prostomium slightly epilobic, dorsal pores from $7 / 8$. Segments simple, sometimes with slight secondary an- 

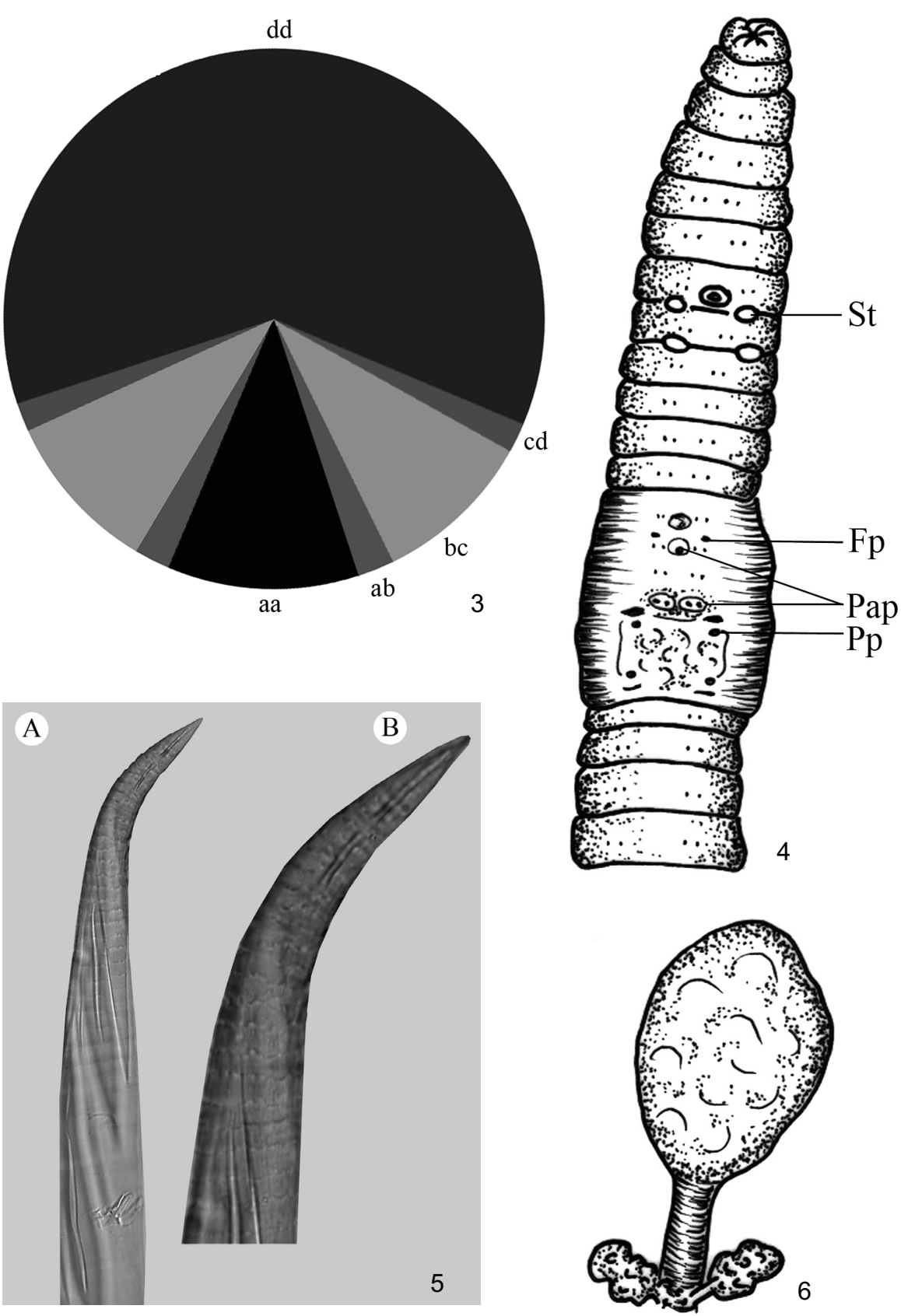

Figs 3-6. Eodriloides metandricus sp. n.: 3 = setal arrangements; $a, b, c, d$ represent setal lines. $4=$ ventral view of the fore-body; Fp $=$ female pore, $\mathrm{Pap}=$ genital papillae, $\mathrm{Pp}=$ prostatic pores, $\mathrm{St}=$ spermathecal pores. $5=$ penial seta; $\mathrm{A}=$ tip of the seta, $\mathrm{B}=$ ornamentation. $6=$ spermatheca 
nulation. Setae visible from segment 2, eight per segment in closely paired regular rows. Setal formula after clitellum $a a: a b: b c: c d: d d=6.5: 1.25: 5.5: 1: 35$ (Fig. 3). Setae of 17, 19 modified to penial setae, genital setae lacking. Spermathecal pores paired prominent slits in the intersegmental furrow 7/8, 8/9 lateral to seta $b$. Clitellum saddle-shaped on 13-19. Female pores in 14 , presetal and slightly lateral to $b$. Two pairs of prostatic pores in 17 and 19 just at the base of seta $b$, joined by almost straight seminal grooves, running outside $b$. Male pores minute, externally not visible on 18 , within the seminal grooves. Genital markings unpaired as three or four mid-ventral, intrasegmental papillae located in 7, 13, 14 and paired in 16 around the ventral setae (Fig. 4).

First septum visible 5/6, septa 6/7-11/12 thickened. One large oesophageal gizzard in 5. Dorsal vessel single throughout, last pair of hearts in 13. Excretory system holoic, avesiculate. Calciferous glands missing but the oesophagus in 9-12 highly vascular. Intestine begins in 16, typhlosole lacking. Metandric. One pair of functional testis and iridescent male funnel in 11, accompanied by a pair of vestigial, not iridescent male funnel in 10 . Seminal vesicles a single pair in 12. One pair of moderate sized ovaries in 13. Two pairs of tubular prostates of similar size in 17 and 19, somewhat coiled and confined to their own segment. Penial setae small, ca. $1 \mathrm{~mm}$ in length and $0.035 \mathrm{~mm}$ in diameter. The tip slightly bent, ornamentation dense transversal serrations (Fig. 5). Two pairs of spermathecae in 8 and 9. Ampulla slightly elongate, oval, duct almost as long as the ampoule. A pair of frontfacing, acinous diverticulum joins to the duct just above the spermathecal pore (Fig. 6).

Remarks - The new species is close to Eodriloides voeltzkowi (Michaelsen, 1907) comb. nov. but differs from it in its smaller dimensions (96 vs. $120 \mathrm{~mm}$ ), in the metandric condition of the male apparatus (vesicles in $12 v s .9,12$ ) and in the intersegmental openings of spermathecae (vs. segmental on the rim of 8 and 9).

\section{Howascolex proprioporus Csuzdi, Razafindrakoto et Hong sp. n.} (Figs 7-10)

Material examined - Holotype: HNHM AF/5692 clitellate adult, Tsararano, Marovay District, Madagascar, $16^{\circ} 10^{\prime} 55.99^{\prime \prime} \mathrm{S}, 46^{\circ} 39^{\prime} 44.95^{\prime \prime} \mathrm{E}, 48 \mathrm{~m}$ a.s.l., mixed forest, soil and litter. 03.03.2017, Leg. Yong Hong \& Malalatiana Razafindrakoto. Paratypes: HNHM AF/5693 6 clitellate adult ex., HNHM AF/5694 1 clitellate adult ex. Locality and date same as of Holotype. HNHM AF/5696 4 clitellate adult ex., Ankazomborona, Marovay District, Madagascar, $16^{\circ} 06^{\prime} 35.73^{\prime \prime} \mathrm{S}, 46^{\circ} 46^{\prime} 58.13^{\prime \prime} \mathrm{E}, 48 \mathrm{~m}$ a.s.l., mixed forest, soil and litter. 03.03.2017, Leg. Yong Hong \& Malalatiana Razafindrakoto. HNHM AF/5697 2 clitellate adult ex., Ambodimanga, Ankarafantsika District, Madagascar, $16^{\circ} 19^{\prime} 27.91^{\prime \prime}$, $46^{\circ} 49^{\prime} 52.90^{\prime \prime} \mathrm{E}, 83 \mathrm{~m}$ a.s.l., mixed forest, soil and litter. 04.03.2017, Leg. Yong Hong \& Malalatiana Razafindrakoto.

Etymology - The specific epithet refers to the closely paired genital pores.

Diagnosis - Length 55-77 $\mathrm{mm}$, diameter 3-4.5 $\mathrm{mm}$. Colour pale, pigmentation lacking. First dorsal pore in 12/13. Clitellum circular on 13-18. + 14 closely paired midventral. Prostatic pores closely paired on 17, 19. Spermathecal pores closely paired, segmental on small midventral papillae on 8 , 9. Spermathecae with an oval ampoule, and a half as long duct bearing a small multilocular diverticulum at the basis of the duct. Gizzard large in 5?, last pair 
of hearts in 13. Calciferous glands large, extramural in 15. Excretory system meroic with ventral megameronephridia. Functionally metandric, vesicles in 12. Penial setae present, length $0.7 \mathrm{~mm}$, diameter $0.02 \mathrm{~mm}$. Tip pointed, slightly bent, ornamentation scattered teeth.

Description - Length of the holotype $77 \mathrm{~mm}$, width (postclitellar) $4.5 \mathrm{~mm}$. Segments No. 191. Paratypes 55-68 mm in length and 3-4 mm in diameter, segment No. 159-184.
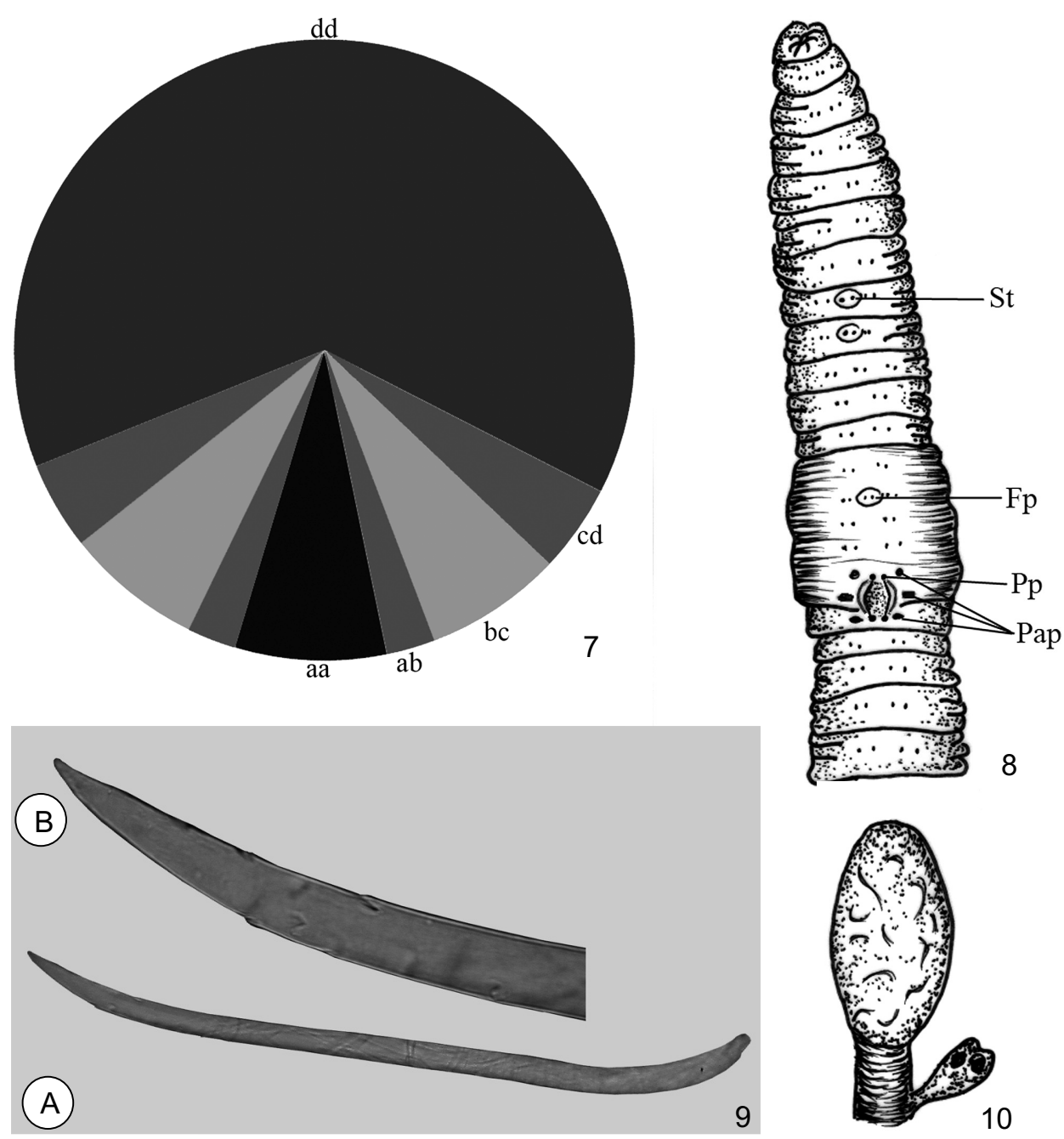

Figs 7-10. Howascolex proprioporus sp. n.: $7=$ setal arrangements; $a, b, c, d$ represent setal lines. 8 = ventral view of the fore-body; $\mathrm{Fp}=$ female pore, $\mathrm{Pap}=$ genital papillae, $\mathrm{Pp}=$ prostatic pores, $\mathrm{St}=$ spermathecal pores. $9=$ penial seta; $\mathrm{A}=$ the whole seta, $\mathrm{B}=$ tip of the seta. $10=$ spermatheca 
Colour greyish, pigmentation absent. Prostomium schizolobic, dorsal pores from 12/13. Segments before clitellum clearly triannulate, after clitellum not so expressed. Setae visible from segment 2, eight per segment in moderately paired regular rows. Setal formula after

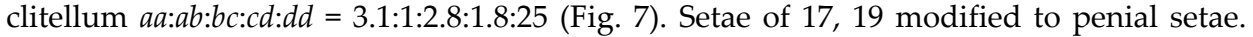
Genital setae lacking. Spermathecal pores segmental, closely paired on midventral papillae in segments 8 and 9. Clitellum circular on 13-18. Female pores closely paired, midventral on 14. Two pairs of prostatic pores in 17 and 19 ventral to setae $a$, joined by angle-quotes shaped seminal grooves, running between $a-a$. Male pores minute, externally not visible on 18, within the seminal grooves. Paired genital markings present in 17, 18, 19 (Fig. 8).

First septum visible $8 / 9$, septa 9/10-12/13 slightly thickened. One large oesophageal gizzard in front of the first septum (possibly in 5). Dorsal vessel single throughout, last pair of hearts in 13. Excretory system meroic throughout with ca. 14 minute, biramous meronephridia and one ventral row of larger meronephridia (megameronephridia?) per side. Calciferous glands large, extramural in 15. Intestine begins in 17, typhlosole large, bilobate. Metandric. One pair of functional testis and iridescent male funnel in 11. There is a vestigial, not iridescent male funnel in 10 and a single pair of seminal vesicles in 12 . One pair of ovaries in 13. Two pairs of tubular prostates of similar size in 17 and 19, somewhat coiled and confined to their own segment. Penial setae small, ca. $0.7 \mathrm{~mm}$ in length and 0.02 $\mathrm{mm}$ in diameter. The tip pointed, slightly bent, ornamentation scattered small teeth (Fig. 9). Two pairs of spermathecae in 8 and 9. Ampulla ovoid, duct $c a$. half as long as the ampoule. A stalked diverticulum containing 3-4 sperm-balls joins to the duct just above the spermathecal pore (Fig. 10).

Remarks - This species is unique in Howascolex by its medially closened genital pores.

\section{Howascolex vohimanus Razafindrakoto, Blanchart et Csuzdi sp. n. (Figs 11-15)}

Material examined - Holotype: HNHM AF/5698 clitellate adult, Vohimana Reserve, Madagascar, $18^{\circ} 55^{\prime} 13.0800^{\prime \prime} \mathrm{S}, 48^{\circ} 31^{\prime} 03.36^{\prime \prime} \mathrm{E}$, rainforest. Leg. Malalatiana Razafindrakoto, Eric Blanchart, 17.04.2008. Paratypes: HNHM AF/5699 1 clitellate adult +1 aclitellate adult ex. Locality and date same as of holotype.

Etymology - The specific epithets refers to the type locality, Vohimana Nature Reserve.

Diagnosis - Length 80-102 mm, diameter $4 \mathrm{~mm}$. Colour pale, pigmentation lacking. First dorsal pore in 11/12. Clitellum saddle-shaped on 13-18. ㅇ 14 presetal in $b$. Prostatic pores paired on 17, 19. Spermathecal pores segmental on 8,9 between $a-b$. Spermathecae with an elongated oval ampoule, and a third as long duct bearing several small intramural sperm chambers. Free diverticulum lacking. Gizzard large in 5, last pair of hearts in 13. Calciferous glands large, intramural in 15. Excretory system meroic with large ventral megameronephridia. Holandric, vesicles in 9, 12. Genital setae present, length ca. $1.3 \mathrm{~mm}$, diameter $0.025 \mathrm{~mm}$, ornamentation small scales. Penial setae slightly undulated, length ca. $4 \mathrm{~mm}$, diameter $0.01 \mathrm{~mm}$, ornamentation lacking. 

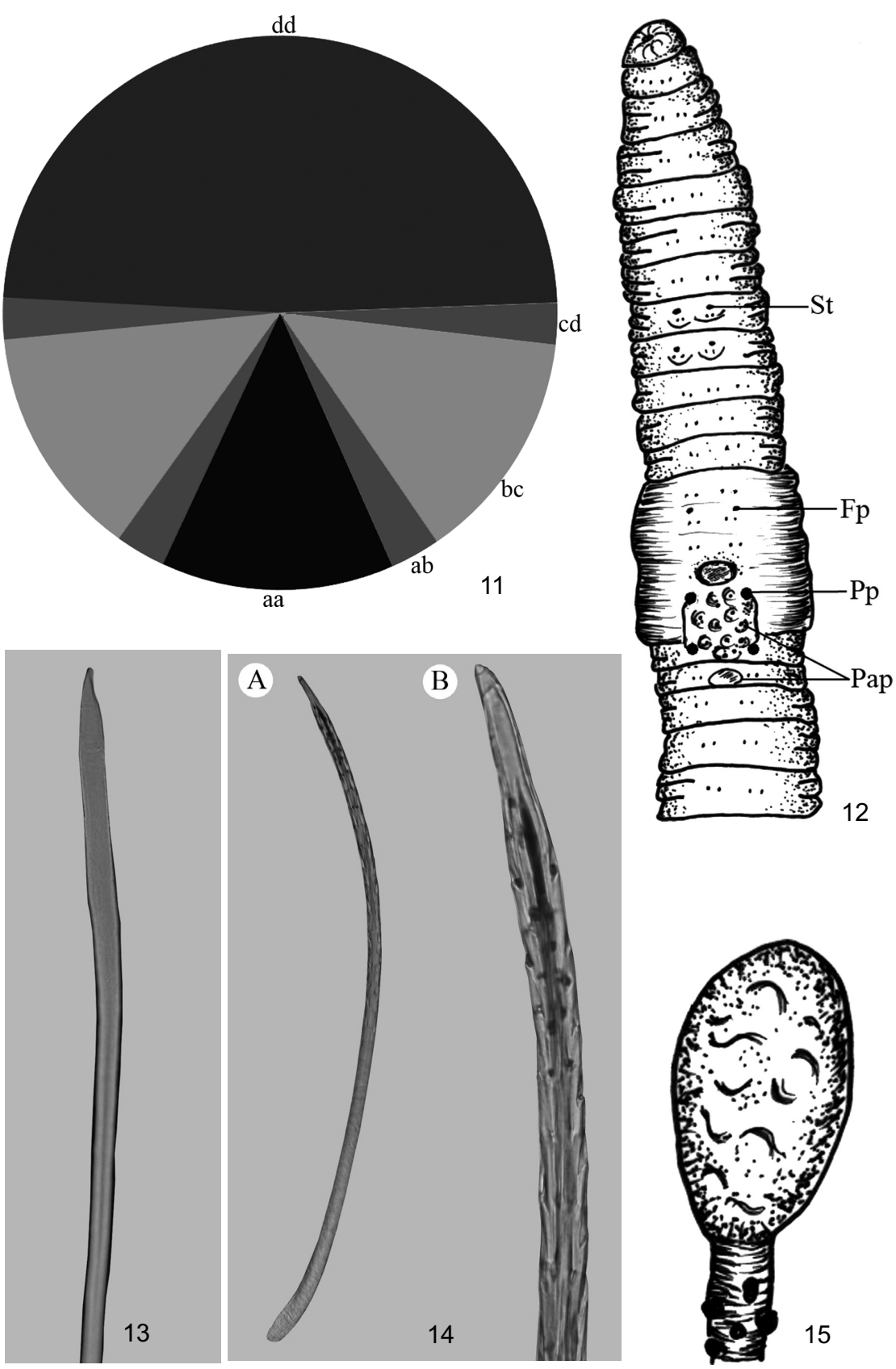

Figs 11-15. Howascolex vohimanus sp. n.: $11=$ setal arrangements; $a, b, c, d$ represent setal lines. $12=$ ventral view of the fore-body; $\mathrm{Fp}=$ female pore, $\mathrm{Pap}=$ genital papillae, $\mathrm{Pp}=$ prostatic pores, $\mathrm{St}=$ spermathecal pores. $13=$ tip of the penial seta. $14=$ genital seta; $\mathrm{A}=$ the whole seta, $\mathrm{B}=$ tip of the seta. 15 = spermatheca 
Description - Length of the holotype (posterior amputee) $80 \mathrm{~mm}$, width (postclitellar) $4 \mathrm{~mm}$. Segments No. 123. Adult paratypes $102 \mathrm{~mm}$ in length and $4 \mathrm{~mm}$ in diameter, segment No. 160. Colour greyish, pigmentation absent. Prostomium schizolobic, dorsal pores from 11/12. Segments before clitellum clearly triannulate, after clitellum not so expressed. Setae visible from segment 2, eight per segment in moderately paired regular

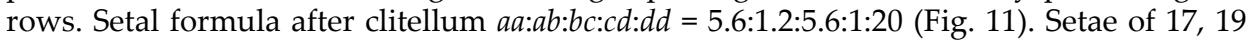
modified to penial setae, of 8,9 modified to genital setae. Spermathecal pores segmental on 8,9 between setae $a-b$. Clitellum saddle-shaped on 13-18. Female pores on 14 presetal in line with setae $b$. Two pairs of prostatic pores in 17 and 19 somewhat ventral to setae $b$, joined by almost straight seminal grooves. Male pores externally not visible on 18 , within the seminal grooves. Genital papillae around $a b$ of 8 and 9, scattered genital markings on 16, 20 and inside the genital field (Fig. 12).

First septum visible 5/6, septa 8/9-11/12 thickened. One large oesophageal gizzard in 5. Dorsal vessel single throughout, last pair of hearts in 13. Excretory system with a pair of large ventral megameronephridia and several small, hardly recognizable meronefridia scattered on the body wall. Calciferous glands large, intramural in 15. Intestine begins in 18, typhlosole small, lamellar. Holandric. Two pairs of testes and iridescent male funnels in 10, 11 and vesicles in 9,12. One pair of ovaries in 13. Two pairs of tubular prostates of similar size in 17 and 19, large but confined to their own segment. Penial setae long, thin and slightly undulated, $c a .4 \mathrm{~mm}$ in length and $0.01 \mathrm{~mm}$ in diameter. Ornamentation lacking (Fig. 13). Genital setae ca. $1.3 \mathrm{~mm}$ in length and $0.025 \mathrm{~mm}$ in diameter, the ornamentation consist of scattered denticulate scales (Fig. 14). Two pairs of spermathecae in 8 and 9. Ampulla elongated sac-shaped, duct $c a .1 / 3$ as long as the ampoule containing several intramural sperm chambers. Free spermathecal diverticulum lacking (Fig. 15).

Remarks - The new species is similar to H. hyalochaeta (Michaelsen, 1907) comb. nov., but differs from it in the segmental spermathecal pores and the much longer penial setae. In the segmental spermathecal pores and the presence of genital setae $H$. vohimana sp. $\mathrm{n}$. is similar to $H$. farafangana Csuzdi, Razafindrakoto et Hong, 2016 as well, but clearly differs from it in the structure of the spermathecae.

\section{Acanthodrilus hesperus Razafindrakoto, Blanchart et Csuzdi sp. $\mathrm{n}$.} (Figs 16-20)

Material examined - Holotype. HNHM AF/5673 clitellate adult. Morondava, Madagascar, $20^{\circ} 17^{\prime} 40.9^{\prime \prime}$ S, $44^{\circ} 19^{\prime} 22.2^{\prime \prime}$ E. 10.02.2010. Leg. Malalatiana Razafindrakoto. Paratypes ZMUA/035, 2 clitellate adult ex. Locality and date same as of holotype.

Etymology - From the Latin hesperus = western, refers to the westernmost occurrence of the pacific genus Acanthodrilus.

Diagnosis - Length 115-125 mm, diameter 3.5-4 mm. Colour reddishbrown. First dorsal pore in 8/9. Clitellum saddle-shaped on 13-19. $q 14$ presetal in $b$. Prostatic pores paired on 17, 19. Spermathecal pores segmental on the rim of segments 8,9 in setal line $a$. Spermathecae with an elongated oval ampoule, and short duct bearing two unstalked acinuous diverticula. Giz- 
zard large in 5, last pair of hearts in 13. Calciferous glands lacking, vascular oesophagus in 11-13. Excretory system holoic with J-shaped nephridial bladders. Holandric, vesicles in 9, 11, 12. Penial setae present, ectal third slightly bulged, tip spoon-shaped, length ca. $1.4 \mathrm{~mm}$, diameter $0.0375 \mathrm{~mm}$, ornamentation scattered serrations.

Description - Length of the holotype $110 \mathrm{~mm}$, width (postclitellar) $4 \mathrm{~mm}$. Segments No. 152, the last several segments regenerated. Paratypes $120 \mathrm{~mm}$ in length and 3.5-4 mm in diameter, segment No. 304-315. Colour dorsally reddish-brown at the front of the body. Prostomium prolobic, dorsal pores from 8/9. Segments with slight secondary annulation. Setae visible from segment 2, eight per segment in closely paired regular rows. Setal formula after clitellum $a a: a b: b c: c d: d d=7.5: 1.25: 7.5: 1: 30$ (Fig. 16). Setae of 17, 19 modified to penial setae, genital setae lacking. Spermathecal pores paired, segmental, on the rim of the segments 8, 9 in line with setae $a$. Clitellum saddle-shaped on 13-19. Female pores in 14, presetal in the setal line $b$. Two pairs of prostatic pores in 17 and 19 just at the base of seta $b$, joined by slightly gibbous seminal grooves. Male pores minute, externally not visible on 18, within the seminal grooves. Genital markings not developed (Fig. 17).

First septum visible 5/6, septa 6/7-8/9 moderately 5/6, 9/10 slightly thickened. One large oesophageal gizzard in 5. Dorsal vessel single throughout, last pair of hearts in 13. Excretory system holoic with J-shaped nephridial bladders (Fig. 18). Calciferous glands missing, but the oesophagus in 11-13 highly vascular. Intestine begins in 16, typhlosole lacking. Two pair of testes and iridescent male funnels in 10,11. Large seminal vesicles in $9,11,12$ those in 9 much reduced. One pair of moderate sized ovaries in 13. Two pairs of tubular prostates of similar size in 17 and 19, somewhat coiled and confined to their own segment. Penial setae $c a .1 .4 \mathrm{~mm}$ in length and $0.0375 \mathrm{~mm}$ in diameter. The ectal third slightly bulged, tip spoon-shaped, ornamentation scattered serrations (Fig. 19). Two pairs of spermathecae in 8 and 9. Ampulla elongate, duct short. A pair of cross-facing, multilobous diverticulum, sits on the duct just above the spermathecal pore (Fig. 20).

Remarks - The new species is provisionally placed into the New Caledonian genus Acanthodrilus based on the presence of J-shaped nephridial bladders. However, it differs from all Acanthodrilus species by its duplicate spermathecal diverticula. To clear its exact position further DNA studies are needed.

Vazimbascolex Hong, Razafindrakoto et Csuzdi gen. n.

Diagnosis - Setae closely paired, all ventral. Female pores on 14. Male apparatus acanthodriline with microscolecine reduction. Prostate glands open in 17, male pores in seminal grooves in 17/18. Penial setae present, genital setae lacking. Spermathecal apparatus paired, with duplicate diverticula. Muscular gizzard in 5. Holandric, last pair of hearts in 12. Extramural calciferous glands lacking, large intramural calciferous folds in 12-14. Typhlosole present, excretory system holoic, avesiculate.

Type species - Vazimbascolex alaotranus sp. $\mathrm{n}$. 


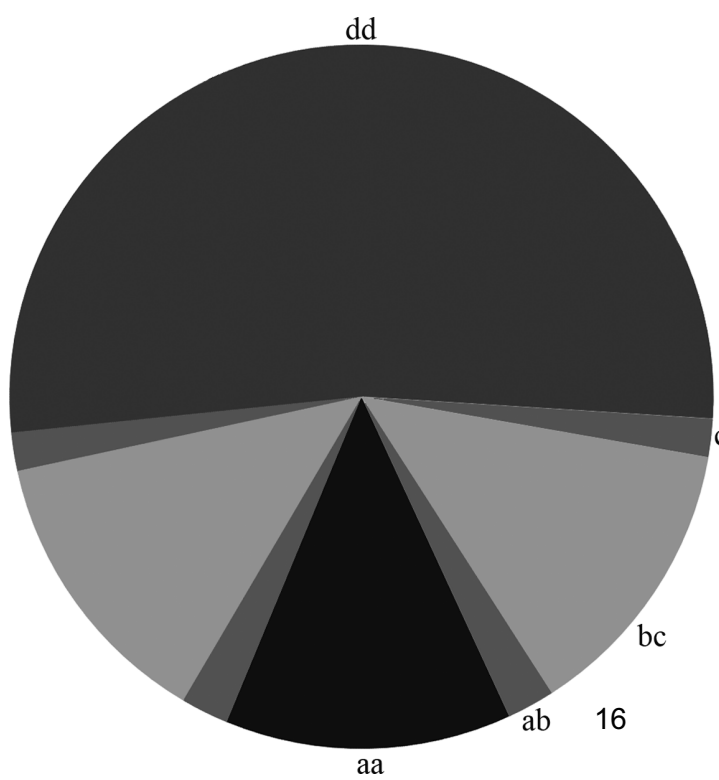

aa
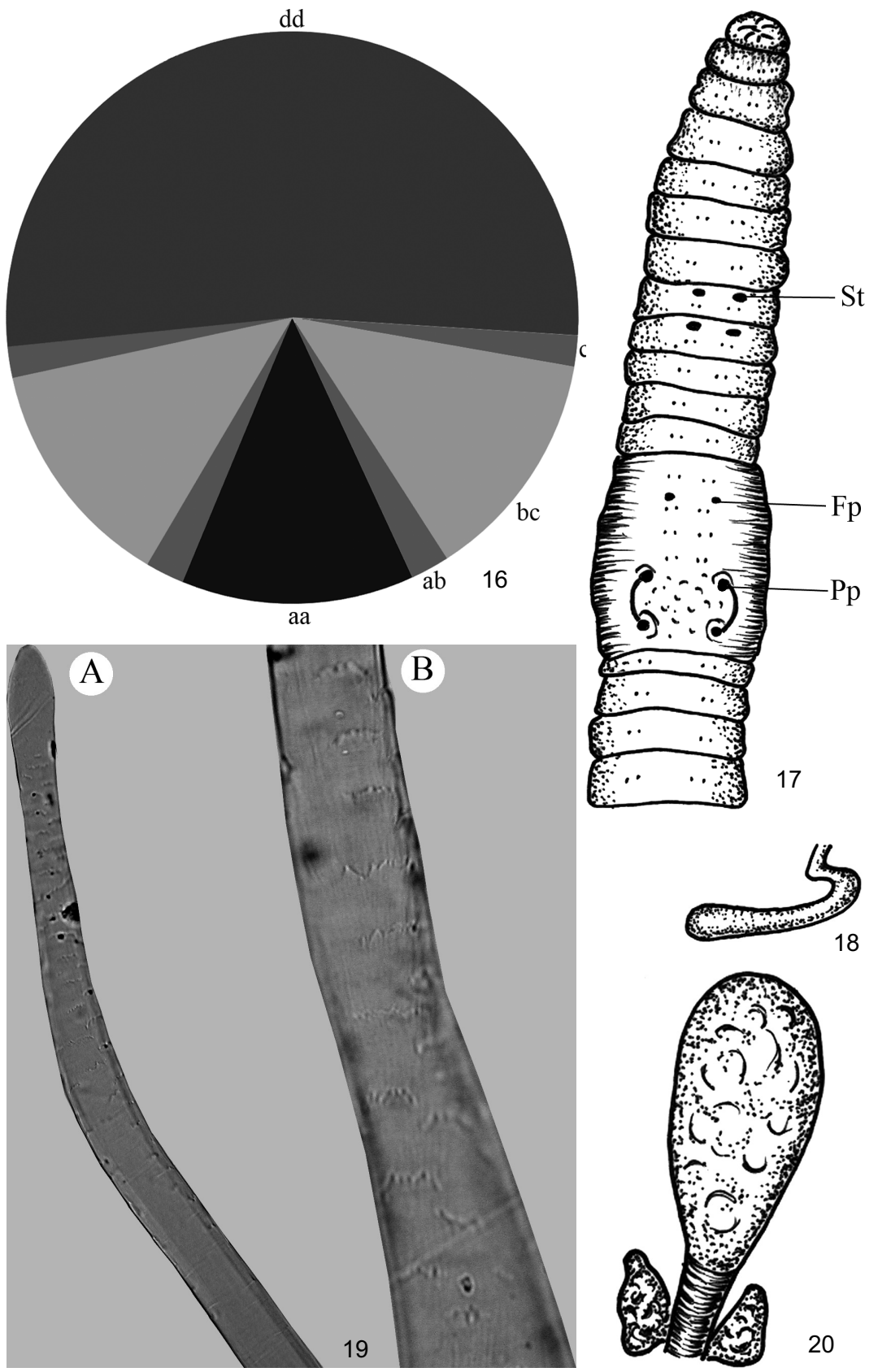

Figs 16-20. Acanthodrilus hesperus sp. n.: 16 = setal arrangements; $a, b, c, d$ represent setal lines. $17=$ ventral view of the fore-body; $\mathrm{Fp}=$ female pore, $\mathrm{Pp}=$ prostatic pores, $\mathrm{St}=$ spermathecal pores. $18=$ nephridial bladder. $19=$ tip of the penial seta, $\mathrm{B}=$ ornamentation. $20=$ spermatheca 


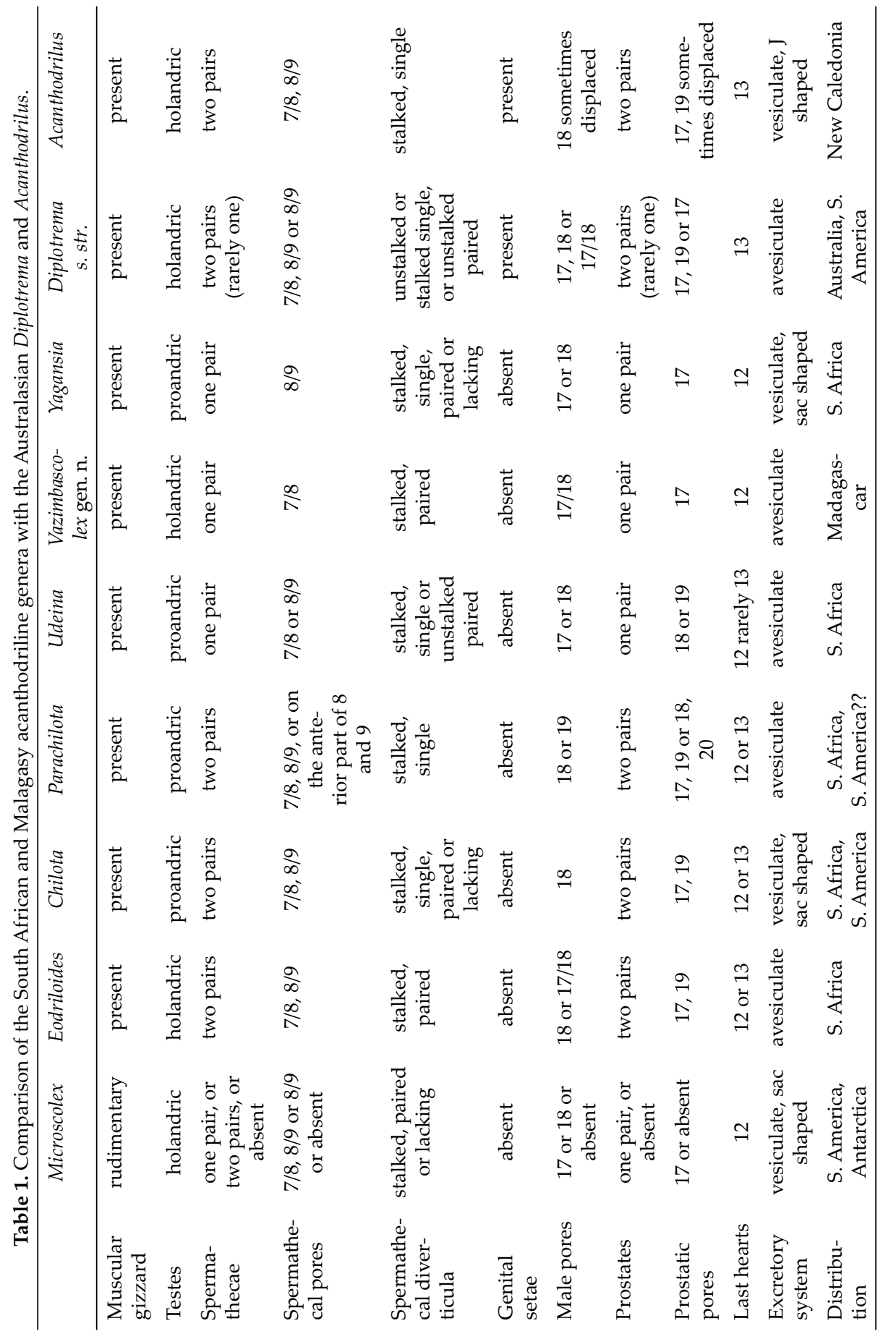


Etymology - The genus name refers to the first settlers of Madagascar, the Vazimba people.

Distribution - Madagascar, Eastern rain forests.

Remarks - The new genus differs from the acanthodriline Diplotrema Spencer, 1900 sensu stricto by its microscolecine reduction, lack of genital setae, presence of paired, stalked spermathecal diverticula and calciferous folds in 12-14. Regarding the spermathecal structure Vazimbascolex gen. n. resembles the holoic avesiculate Eodriloides Zicsi, 1998 but differs from it in its microscolecine reduction and calciferous folds in 12-14. The new genus shows similarities with Udeina Michaelsen, 1910 which also has a single pair of prostates in various positions (PLISKo 2004), but differs from it by the duplicate spermathecal diverticula, presence of a typhlosole and holandric male apparatus (Table 1).

\section{Vazimbascolex alaotranus Hong, Razafindrakoto et Csuzdi sp. n. (Figs 21-24)}

Material examined - Holotype: HNHM AF/5700 clitellate adult, Ambalataretra, District Ambatondrazaka, Alaotra-Mangoro Region, Madagascar. Leg. 25.11.2008, Malalatiana Razafindrakoto. Paratypes: HNHM AF/5701, 4 clitellate adult +4 aclitellate adult ex., Locality and date same as of holotype. HNHM AF/5702, 1 clitellate adult ex., HNHM AF/5703, 2 clitellate adult +1 aclitellate adult ex., Madagascar, Moramanga. Leg. 03.03. 2017, Yong Hong \& Malalatiana Razafindrakoto. locality.

Etymology - The name refers of the geographic region (Alaotra-Mangoro) of the type

Diagnosis - Length 170-195 mm, diameter $4 \mathrm{~mm}$. Colour pale, pigmentation lacking. First dorsal pore in 7/8. Clitellum saddle-shaped on 13-18. $q 14$ presetal in $a b$. Prostatic pores paired on 17, male pores in $17 / 18$. Spermathecal pores in 7/8 lateral to $b$. Spermathecae mushroom-shaped with a short duct bearing two acinuous diverticula. Muscular gizzard in 5, last pair of hearts in 12. Calciferous glands lacking, oesophagus with strong longitudinal folds in segment 12-14. Excretory system holoic avesiculate. Holandric, vesicles in 9, 12. Penial setae present, ectal third slightly bent, length $c a .2 .2 \mathrm{~mm}$, diameter $0.075 \mathrm{~mm}$, ornamentation dense serrations.

Description - Length of the holotype $172 \mathrm{~mm}$, width (postclitellar) $4 \mathrm{~mm}$. Segments No. 229. Adult paratypes $170-195 \mathrm{~mm}$ in length and $4 \mathrm{~mm}$ in diameter, segment No. 265-318. Colour greyish, pigmentation absent. Prostomium epilobic, dorsal pores from $7 / 8$. Segments before clitellum clearly multiannulate, quite prominent after clitellum as well. Setae visible from segment 2, eight per segment in strictly paired regular rows. Setal

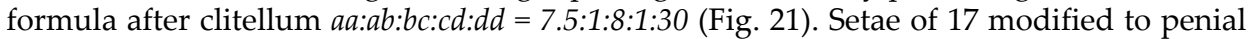
setae, genital setae lacking. Spermathecal pores large slits in $7 / 8$ lateral to setae $b$. Clitellum saddle-shaped on 13-18, if strongly developed covers partly segment 12 as well. Female 

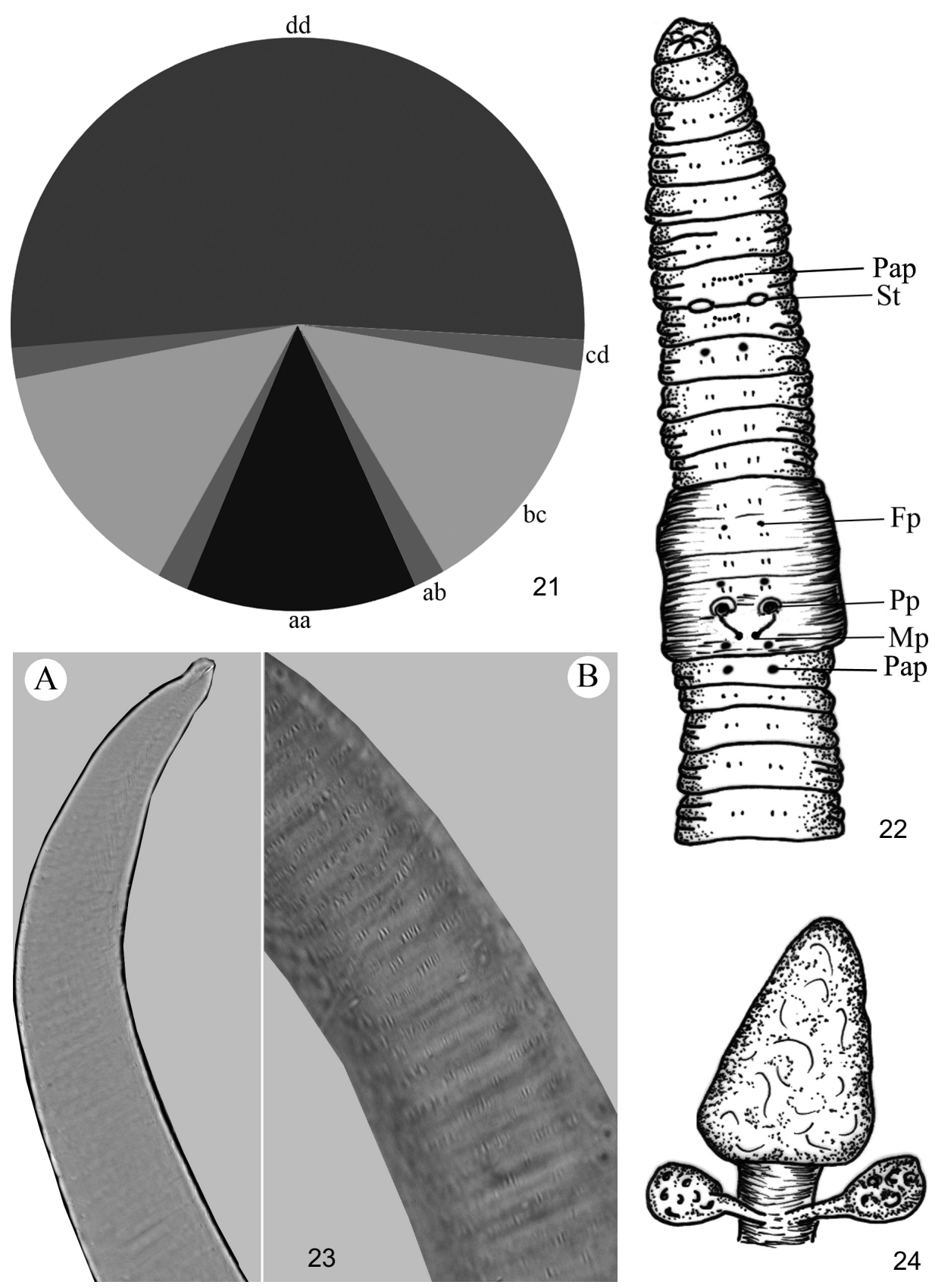

Figs 21-24. Vazimbascolex alaotranus sp. n.: 21 = setal arrangements; $a, b, c$, $d$ represent setal lines. 22 = ventral view of the fore-body; $\mathrm{Fp}=$ female pore, $\mathrm{Mp}=$ male pore, $\mathrm{Pap}=$ genital papillae, $\mathrm{Pp}=$ prostatic pores, $\mathrm{St}=$ spermathecal pores. $23=$ penial seta; $\mathrm{A}=$ tip of the penial seta, $\mathrm{B}=$ ornamentation. $24=$ spermatheca 
pores on 14 presetal in $a b$. A single pair of prostatic pores in 17 on prominent protuberances. From the prostatic pores highly curved seminal grooves run to the male pores in $17 / 18$. Small genital papillae arranged in lines between $a-a$ in 7 and 8 and unpaired papillae just before setae $a b$ on 9, 16, 18, 19 (Fig. 22).

First septum visible 5/6, septa 6/7-10/11 thickened. One moderate oesophageal gizzard in 5. Dorsal vessel single throughout, last pair of hearts in 12. Excretory system holoic, avesiculate. Calciferous glands lacking, the oesophagus bears prominent longitudinal folds in segment 12-14. Intestine begins in 16, typhlosole small, lamellar. Holandric. Two pairs of testes and iridescent male funnels in 10,11 and vesicles in 9, 12. One pair of ovaries in 13. A single pair of tubular prostates in 17, large but confined to their own segment. Penial setae strong, ca. $2.2 \mathrm{~mm}$ in length and $0.075 \mathrm{~mm}$ in diameter. The tip slightly bent, ornamentation dense serrations (Fig. 23). One pair of spermathecae in 8. Ampulla mushroom-shaped, duct $c a .1 / 3$ as long as the ampoule. A pair of acinuous diverticula joins on the frontal face of the duct just above the spermathecal pore (Fig. 24).

\section{DISCUSSION}

Before starting a new earthworm survey in Madagascar (RAzAFIndRAкото et al. 2010) five acanthodrilid species were registered for the country; Acanthodrilus majungianus Michaelsen, 1897, Acanthodrilus voeltzkowi Michaelsen, 1897, Howascolex madagascariensis Michaelsen, 1901, Microscolex (Notiodrilus) hyalochaeta Michaelsen, 1907 and Eodrilus dauphinianus Michaelsen, 1910. Apart from madagascariensis belonging to the Malagasy endemic genus Howascolex the other species' generic affiliation was always problematic. In her revision of the South African acanthodriline earthworms PICKFORD (1937) finally relegated all of them to the Australian genus Eodrilus Michaelsen, 1907. As the genus Eodrilus proved to be a synonym of Diplotrema Spencer, 1900 (JAMIESON 1971) hyalochaeta, majungianus voeltzkovi and dauphinianus should have been transferred to Diplotrema as well, however, formally it was proposed just recently by Fragoso and Rojas (2016), contrary to the Central and South American 'Eodrilus' species which were relegated provisionally to Diplotrema by James (1990). However, theses actions extremely extended the borders of the genus Diplotrema morphologically (all the acanthodriline species with avesiculate nephridial system regardless of the structure of the spermathecae, presence or absence of gizzard, presence or absence of genital setae) and geographically as well (distributed in Australia, Central and South America and even Madagascar and South Africa). This synonymy is really too wide and was not accepted by several authors.

Reynolds and Righi (1994) argued for retaining Eodrilus for the Central and South American taxa, ZIcsi (1998) erected the genus Eodriloides to accommodate the South African species differing from Diplotrema by the stalked bidiverticulate condition of the spermathecae and lack of genital setae. 
Dyne and Jamieson (2004) remarked that the Mexican species described by James (1990) on morphological grounds are seemingly close to Diplotrema but their phylogenetic relationship with the Australian species is questionable. In a recent paper Fragoso and Rojas (2018) also agreed upon this statement and suggested that the South American Diplotrema like species represent phylogenetically a different group.

Two earlier described Malagasy acanthodriline species majungianus and voeltzkowi possess purely holoic nephridial system and share the stalked bidiverticulate condition of spermathecae with the newly described Eodriloides metandricus and the South African Eodriloides species sensu ZIcsi (1998). They lack well-developed calciferous diverticula and neither have genital setae therefore, they are separate from the Malagasy Howascolex. Whether they are more closely related to the South African Eodriloides or form a clade with the Malagasy Howascolex further molecular studies should determine. These uncertainties exist also in case of the newly described genus Vazimbascolex gen. $\mathrm{n}$. It is the only Malagasy acanthodriline genus with last pair of hearts in 12 and a single pair of spermathecae in $7 / 8$. In these features it resembles to the South African Udeina Michaelsen, 1910, but the bidiverticulate spermathecae and the numerous papillae around the spermathecal and prostate segments make it similar to the Malagasy species.

The differences between the meroic Howascolex madagascariensis and the holoic species are quite scarce and it seems that the meroic condition evolved in situ in the island. Nevertheless, the doubtfully meroic Howascolex hyalochae$\mathrm{ta}$ and $\mathrm{H}$. dauphinianus share other characteristics with the so far known Howascolex species; namely the presence of well-developed calciferous glands in the region of 15-16 and the spermathecae never truly bidiverticulate. It is also remarkable that almost all Howascolex species (exl. H. proprioporus) possess densely scattered papillae around the male genital field and the openings of the spermathecae.

It is worth noting the presence of a holoic diverticulate acanthodriline species in Madagascar. All the four endemic holoic African genera (Eodrioides, Parachilota, Udeina and Vazimbascolex) are avesiculate, moreover the J-shaped nephridial bladder is an exclusive character for the type genus Acanthodrilus Perrier, 1872. However, Acanthodrilus is characterized also by the presence of genital setae which lacks in $A$. hesperus sp. $\mathrm{n}$. and also the presence of bidiverticulate spermathecae suggests an independently acquired holoic vesiculate condition.

Acknowledgement - This study was supported by the National Research Foundation of Korea (NRF) funded by the Ministry of Education (NRF-2015R1D1A2A01057305). 


\section{REFERENCES}

Cognetti de Martis, L. (1906): Lombrichi di Madagascar e dell'isola Riunione. - Bollettino dei Musei di Zoologia ed Anatomia comparata della R. Universitádi Torino 21(537): 1-9.

Csuzdi Cs., Razafindrakoto, M. \& Blanchart, E. (2012): New and little known earthworm species from Central Madagascar (Oligochaeta: Kynotidae). - Zootaxa 3578: 36-42. https://doi.org/10.11646/zootaxa.3578.1.2

Csuzdi, Cs., Razafindrakoto, M. \& Hong, Y. (2016): The second species of the endemic Malagasy earthworm genus Howascolex Michaelsen, 1901; Howascolex farafangana sp. n. (Clitellata, Megadrili). - African Invertebrates 57(2): 83-91. https://doi. org/10.3897/AfrInvertebr.57.10048

Csuzdi, Cs., Razafindrakoto, M. \& Hong, Y. (2017a): Three new species of Kynotus from the Central Highlands of Madagascar (Clitellata, Megadrili). - European Journal of Taxonomy 336: 1-14. https://doi.org/10.5852/ejt.2017.336

Csuzdi, Cs., Pearlson, O. \& PavlíčeK, T. (2017b): New Acanthodrilus species from New Caledonia (Clitellata, Megadrili, Acanthodrilidae). - Journal of Natural History 51: 1899-1912. https://doi.org/10.1080/00222933.2017.1355500

Dyne, G. \& Jamieson, B.G.M. (2004): Native Earthworms of Australia II (Megascolecidae, Acanthodrilinae). - Department of the Environment and Heritage, Australian Government, NSW, 200 pp.

Fragoso, C. \& Rojas, P. (2016): Lavellodrilus notosetosus sp. nov. (Annelida, Crassiclitellata, Acanthodrilidae): a new Mexican earthworm with uncommon characters, revealed by a preliminary revision of subfamily Acanthodrilinae. - Zootaxa 4154: 101-138. https://doi.org/10.11646/zootaxa.4154.2.1

Fragoso, C. \& Rojas, P. (2018): New Diplotrema and Lavellodrilus earthworm species from southern Mexico (Annelida, Crassiclitellata, Acanthodrilidae). - Zootaxa 4496: 414-430. https://doi.org/10.11646/zootaxa.4496.1.31

James, S. W. (1990): Diplotrema murchiei and D. papillata, new earthworms (Oligochaeta: Megascolecidae) from Mexico. - Acta Zoologica Mexicana 38: 18-27.

Jamieson, B. G. M. (1971): A review of the megascolecoid earthworm genera (Oligochaeta) of Australia. Part II. The subfamilies Ocnerodrilinae and Acanthodrilinae. - Proceedings of the Royal Society of Queensland 82: 95-108.

Jamieson, B. G. M. \& BennetT, J. D. (1979): New species of Acanthodrilinae and a new genus of Perionychini (Oligochaeta, Megascolecidae) from New Caledonia, their phylogeny and zoogeography. - Bulletin du Muséum national d'histoire naturell Paris 2: 353-403.

Jamieson, B. \& Dyne, G. (1976): The acanthodrile earthworm genus Microscolex (Diplotrema) (Megascolecidae: Oligochaeta) in the Northern Territory of Australia. -Australian Journal of Zoology 24(3): 445-476. https://doi.org/10.1071/ZO9760445

JulKa, J. M. (1988): Fauna of India. Megadrile Oligochaeta (Earthworms). Family Octochaetidae. - Zoological Survey of India, Calcutta, $400 \mathrm{pp}$.

Michaelsen, W. (1897): Die Terricolen des Madagassischen Inselgebiets. - Abhandlungen der Senckenbergischen Naturforschenden Gesellschaft 21: 217-252.

Michaelsen, W. (1907): Oligochaeten von Madagaskar, den Comoren und anderen Inseln des westlichen Indischen Ozeans. - Reise in Ostafrika von A. Voeltzkow in den Jahren 1903-05, Wissenschaftliche Ergebnisse 2: 41-50.

Myers, N., Mittelmeier, R. A., Mittelmeier, C. G., da Fonseca, G. B. A. \& Kent, J. (2000): Biodiversity hotspots for conservation priorities. - Nature 403(6772): 853-858. https:// doi.org/10.1038/35002501 
Pickford, G. E. (1937): A Monograph of the Acanthodriline Earthworms of South Africa. - Heffer \& Sons Cambridge, 612 pp.

Razafindrakoto, M., Csuzdi, Cs., Rakotofiringa, S. \& Blanchart, E. (2010): New records of earthworms (Oligochaeta) from Madagascar. - Opuscula Zoologica (Budapest) 41: 231-236.

Razafindrakoto, M., Csuzdi, Cs. \& Blanchart, E. (2011): New and little known giant earthworms from Madagascar (Oligochaeta: Kynotidae). - African Invertebrates 52: 285-294. https://doi.org/10.5733/afin.052.0205

Razafindrakoto, M., Csuzdi Cs., James, S. W. \& Blanchart, E. (2017): New earthworms from Madagascar with key to the Kynotus species (Oligochaeta: Kynotidae). - Zoologischer Anzeiger 268: 126-135. https://doi.org/10.1016/j.jcz.2016.08.001

Reynolds, J. W. \& Righi, G. (1994): On some earthworms from Belize, C.A. with the description of a new species (Oligochaeta: Acanthodrilidae, Glossoscolecidae and Octochaetidae). - Megadrilogica 5(9): 97-106.

Zıcsı, A. (1998): Neue und seltene terrestrische Oligochaeten aus Südafrika. - Mitteilungen aus dem Natur-historischen Museum in Hamburg 95: 59-77.

Received March 18, 2019, accepted June 24, 2019, published August 12, 2019 


\title{
Earthworms of Hungary (Annelida: Oligochaeta, Lumbricidae)
}

\author{
by Cs. Csuzdi \& A. Zicsi
}

This is the first volume of a new series Pedozoologica Hungarica launched by the Hungarian Natural History Museum and the Hungarian Academy of Sciences aiming to present the scientific results of the Hungarian soil zoology school founded by Endre Dudich in the early years of the 1950s.

During these more than fifty years of research a great amount of data have accumulated on the different groups of the pedofauna waiting for monographic elaboration. It is especially true for earthworms where continuous research has been carried out from the end of the $19^{\text {th }}$ century till now.

In this book the authors summarize and critically survey the Hungarian earthworm records and give an account on the systematics and taxonomy of the family Lumbricidae complemented with a key to the inland genera and species.

All the 57 species recorded so far in the country are provided with diagnosis, detailed synonymy list and complete Hungarian distributional data figured in UTM grid maps. Except the peregrine species the European distributions are also given.

The book closes with a short zoogeographic summary of the lumbricid earthworms and a chorological analysis of the species occurring in Hungary.

ISSN 1785-1025

ISBN 9637093818

271 pages, hardback, with $107 \mathrm{~b} / \mathrm{w}$ photos 39 line drawings and 100 distribution maps.

Price: EUR 50, excluding package and postage

Orders should be sent to:

The Library, Hungarian Natural History Museum

H-1088 Budapest, Baross u. 13, Hungary

Fax: (36-1) 3171669 